\title{
Desire for lasting long in bed led to contact allergic dermatitis and subsequent superficial penile gangrene: a dreadful complication of benzocaine- containing extended-pleasure condom
}

\author{
Ashish Sharma, Samarth Agarwal, Gaurav Garg, Siddharth Pandey
}

Department of Urology, King George's Medical University, Lucknow, Uttar Pradesh, India

\section{Correspondence to Dr Ashish Sharma, ashishuc343@gmail.com}

Accepted 10 September 2018

\section{DESCRIPTION}

A 30-year-old non-atopic, non-diabetic man presented with complaints of swelling, pain and patchy blackening of penile skin for the last 3 days. He stated that for improving the duration of sexual intercourse and for better sexual performance, he recently used a new brand of condom, which contained 5\% benzocaine. He, however, denied about the use of any lubricants or topical substance at the time of sexual act. There was no history of fever, inguinal or scrotal swelling, genital trauma, insect bite, known drug allergy, substance abuse or similar complaints in the past. In the past, he was using non-medicated natural rubber latex condom for contraception without any adverse effects. Local examination revealed vesicle eruption, sloughing and patchy blackening of penile skin extending from prepuce to base of penis with a clear demarcation line with non-palpable inguinal lymph nodes suggestive of allergic contact dermatitis as shown in figure 1 . The underlying tunica albuginea, corpora cavernosa and corpora spongiosa were not involved. His routine blood/urine examination and screening work-up for sexually transmitted diseases was unremarkable. Swab culture from penile lesion showed growth of group A beta-haemolytic Streptococcus (S. pyogenes). The patient was managed with culture-specific parenteral antibiotics and multiple sessions of surgical debridement. After
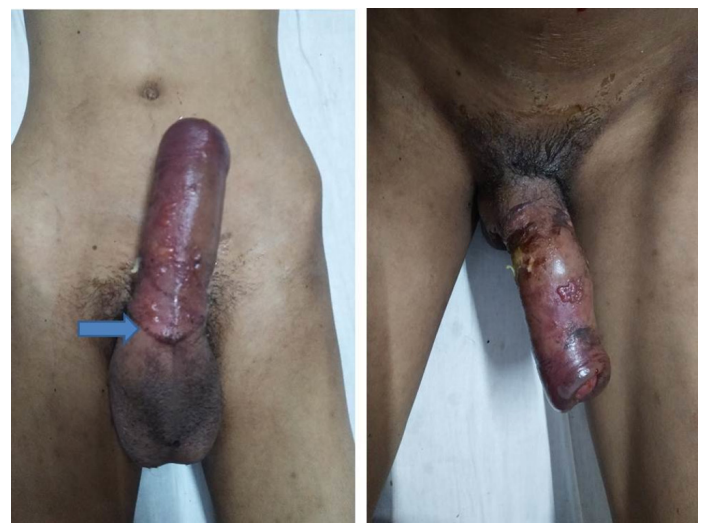

Figure 1 Clinical picture at presentation showing vesicle eruption, sloughing and patchy blackening of superficial penile skin extending from prepuce to root of penis with clear demarcation line (arrow) indicating proximal contact limit of condom.

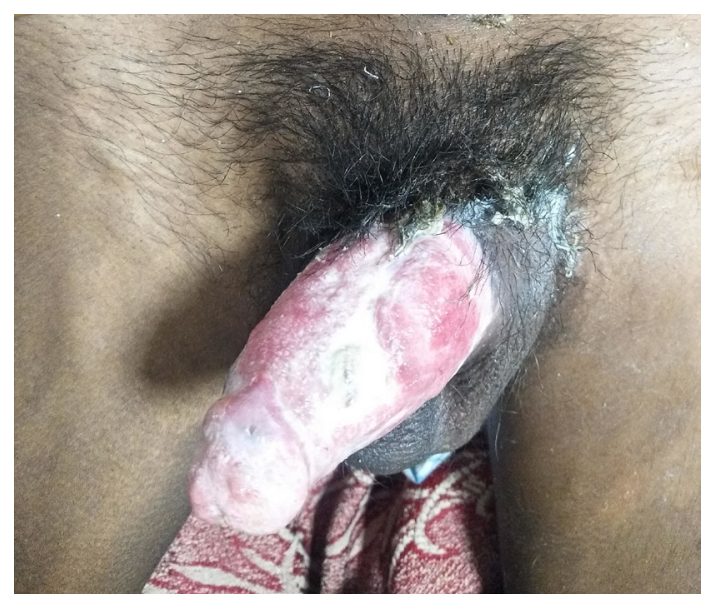

Figure 2 Clinical image showing circumferential global penile skin loss with healthy granulating tissue at 3 weeks after presentation.

3 weeks of treatment, healthy pink granulating penile bed was achieved (figure 2), after which a meshed, split-thickness skin grafting was performed under anaesthesia. The postoperative period was uneventful. The graft dressing was changed on the fifth postoperative day, and it revealed a $100 \%$ take of the graft. Dermatology consultation was also taken and European baseline patch test series (including benzocaine, fragrance mix and nickel sulfate) was performed. ${ }^{1}$ The patch test showed positive patch reactions to benzocaine $(5 \%)$ at 48 hours $(+)$, at 72 hours and 96 hours $(++)$. However, sensitivity to other performed allergens was negative. At 6 months of follow-up, he was doing fine with no sexual or urinary complaints.

Irritant and allergic contact dermatitis of external genitalia has been described previously with various topical medications, lubricants and latex condoms. ${ }^{2}$ Benzocaine $(4.5 \%$ or $5 \%)$ as a local anaesthetic suspending agent is used in extended-pleasure latex condoms for prolonging the duration of sexual intercourse and to decrease premature ejaculation, and it is composed of the ethyl ester of para-aminobenzoic acid. ${ }^{2} 3$ Placucci et al first described a case of benzocaine-induced contact dermatitis due to latex condoms in $1996 .{ }^{4}$ Since then, as little as four such cases have been reported. ${ }^{3-6}$ The authors believe this to be the first ever documented case of allergic contact dermatitis and subsequent penile skin gangrene due to benzocaine-containing latex 
condom. Amide local anaesthetics (lidocaine, bupivacaine and prilocaine) are better tolerated, whereas ester local anaesthetics (benzocaine, procaine, chloroprocaine and tetracaine) have more allergenic reactions. Among the ester anaesthetics, benzocaine has the greatest number of positive results in patch tests. ${ }^{7}$ It has been seen that $5 \%$ of patients who use topical benzocaine become sensitised to it; therefore, long-term uses of it can lead to the appearance of hypersensitivity reactions (less than 1\% of all adverse reactions). ${ }^{8}$ Most of these reactions are T-cell-mediated type IV delayed hypersensitivity reactions. Benzocaine can also cross-react with several other allergens as well.

Superficial penile gangrene secondary to superimposed bacterial infections of irritant contact dermatitis can occur even in sexually active men with no history of previous hypersensitivity. The other predisposing factors for penile gangrene may include diabetes, penile trauma, penile constricting ring, prolonged condom catheter, recent genitourinary procedures

\section{Learning points}

- Superficial penile gangrene secondary to irritant contact dermatitis can occur even in sexually active men with no history of previous hypersensitivity.

- The benzocaine contact dermatitis due to use of latex condoms is an extremely rare clinical entity and the superimposed bacterial infection over contact dermatitis of penis may rarely lead to penile skin gangrene.

- Thorough medical history (especially about past allergic reactions), clinical examinations and patch tests with baseline series/suspicious agent are crucial to make a definitive diagnosis of genital contact dermatitis.

- Early diagnosis and treatment including antibiotics and debridement are needed for successful management of penile skin gangrene. or instrumentations, or penile prosthesis implantation. The reporting of such cases is extremely rare due to feelings of shame and social stigma. It is important that treating clinicians take thorough medical history (especially about past allergic reactions) and perform patch tests with the baseline series/suspiciousagent to make a definitive diagnosis in such cases. Early diagnosis and treatment including parenteral antibiotic, serial debridement and regular dressing is needed in case of evolving or established penile skin gangrene.

Contributors AS and SA: concept, design, supervision, processing, writing of manuscript and critical analysis. GG: supervision, processing, writing of manuscript and critical analysis. SP: concept, supervision, writing of manuscript and critical analysis.

Funding The authors have not declared a specific grant for this research from any funding agency in the public, commercial or not-for-profit sectors.

Competing interests None declared.

Patient consent Obtained.

Provenance and peer review Not commissioned; externally peer reviewed.

\section{REFERENCES}

1 Andersen KE, White IR, Goossens A. In: Johansen JD, Frosch PJ, Lepoittevin JP, eds. Allergens from the European baseline series. 5th edn. Berlin: Heidelberg, SpringerVerlag, 2011:545-91.

2 Caminati M, Giorgis V, Palterer B, et al. Allergy and sexual behaviours: an update. Clin Rev Allergy Immunol 2017.

3 Muratore L, Calogiuri G, Foti C, et al. Contact allergy to benzocaine in a condom. Contact Dermatitis 2008;59:173-4.

4 Placucci F, Lorenzi S, La Placa M, et al. Sensitization to benzocaine on a condom. Contact Dermatitis 1996:34:293.

5 Foti C, Bonamonte D, Antelmi A, et al. Allergic contact dermatitis to condoms: description of a clinical case and analytical review of current literature. Immunopharmacol Immunotoxicol 2004;26:481-5.

6 Ljubojević Hadžavdić S, Gojčeta Burnić S, Hadžavdić A, et al. Erythema of the penis after use of a latex condom-latex allergy or something else? Contact Dermatitis 2018;78:168-9.

7 Warshaw EM, Schram SE, Belsito DV, et al. Patch-test reactions to topical anesthetics: retrospective analysis of cross-sectional data, 2001 to 2004. Dermatitis 2008;19:81-5.

8 Thyssen JP, Menné T, Elberling J, et al. Hypersensitivity to local anaesthetics —update and proposal of evaluation algorithm. Contact Dermatitis 2008;59:69-78.

Copyright 2018 BMJ Publishing Group. All rights reserved. For permission to reuse any of this content visit

http://group.bmj.com/group/rights-licensing/permissions.

BMJ Case Report Fellows may re-use this article for personal use and teaching without any further permission.

Become a Fellow of BMJ Case Reports today and you can:

- Submit as many cases as you like

- Enjoy fast sympathetic peer review and rapid publication of accepted articles

- Access all the published articles

Re-use any of the published material for personal use and teaching without further permission

For information on Institutional Fellowships contact consortiasales@bmjgroup.com

Visit casereports.bmj.com for more articles like this and to become a Fellow 